\title{
P296: Epidemiological profile and management of accidental blood exposure, Bamako
}

\author{
A Traoré ${ }^{*}$, M Dembélé ${ }^{2}$, DS Ouologuem¹, DK Minta', AS Kaya², T Cissé ${ }^{1}$, HA Traoré2 \\ From 2nd International Conference on Prevention and Infection Control (ICPIC 2013) \\ Geneva, Switzerland. 25-28 June 2013
}

\section{Objectives}

The aims of this study were to describe the epidemiological profile, circumstances of occurrence and postexposure practices.

\section{Methods}

We conducted a retrospective study on records of people who were victims of accidental exposure to blood (AES) treated in the Department of Infectious Diseases, in the University Hospital Teaching of Point G, Bamako-Mali over 8 years.

\section{Results}

We collected 40 AES with a male predominance (sexratio $=2$ ). The median age was 32 years [19-54 years]. Our study population was composed of students (42.5\%), physicians (22.5\%), nurses (15\%) and surface technicians (sanitizers) (7.5\%). The AES had occurred mainly in hospitals $(57.5 \%)$ and $20 \%$ in home care. The surgery department was more concerned (45\%). The main circumstances of occurrence were the needle stick (42.5\%); puncture by scalpel $(22.5 \%)$; recapping $(10 \%)$ and the projection on the mucosa (10\%). The majority had done the washing with water / soap (92.5\%) of which $25 \%$ immediately. Eight people were reported after 48 hours. HIV status of the source patient was known in $47.5 \%$ of which $25 \%$ were positive. A lady had a positive HIV serology after accidental blood exposure (seroconversion) At the time of AES, serology for hepatitis $B$ and $C$ were not known in the majority of patients and victims sources. Thirty have benefited from ARV prophylaxis.

\section{Conclusion}

Difficulties encountered in the declaration and management of AES require training of health personnel of University Hospital Teaching of Point G.

\section{Competing interests}

None declared.

\section{Author details}

${ }^{1}$ Service of Infectious Diseases, University Hospital of Point G , Bamako, Mali. ${ }^{2}$ Department of Internal Medicine, University Hospital of Point G, Bamako, Mali.

Published: 20 June 2013

doi:10.1186/2047-2994-2-S1-P296

Cite this article as: Traoré et al.: P296: Epidemiological profile and management of accidental blood exposure, Bamako. Antimicrobial Resistance and Infection Control 2013 2(Suppl 1):P296.

Submit your next manuscript to BioMed Central and take full advantage of:

- Convenient online submission

- Thorough peer review

- No space constraints or color figure charges

- Immediate publication on acceptance

- Inclusion in PubMed, CAS, Scopus and Google Scholar

- Research which is freely available for redistribution
C Biomed Central 